\title{
Effects of Buserelin acetate and semen extension on fertility in rabbit does under
} artificial insemination

${ }^{1 *}$ Ewuola E. O. ${ }^{1}$ Omotosho G. A and A. A. Adeyemi ${ }^{2}$

${ }^{1}$ Animal Physiology and Bioclimatology Unit, Department of Animal Science, University of Ibadan, Ibadan, Nigeria

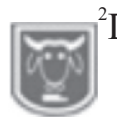

${ }^{2}$ Department of Animal Science, Obafemi Awolowo University, Ile-Ife, Nigeria

*Corresponding author Email: eoewuola@gmail.com; GSM: +2348060862361

\section{Abstract}

The productivity of rabbit farms can be increased and become more homogeneous through the use of Artificial Insemination (AI). However, this possibility is limited with low conception in artificially inseminated does without ovulation induction. This study aimed at determining the conception rate of rabbit does induced with buserelin acetate and inseminated with extended semen at varied dilution ratio. A total number of Twenty eight multiparous non-lactating rabbit does were randomly allotted into four treatments housed individually in a completely randomised design. Rabbits were used as a teaser for semen collection using an artificial vagina and after semen collection and evaluation; ejaculates from ten bucks with more than 60\% motility were pooled and extended. Forty eight hours before the AI, the does were hormonally synchronized (i.m) for oestrus with 20IU PMSG. Does in treatment 1(control) were inseminated with unextended semen without buserelin but injected with normal saline, while does on treatments 2, 3 and 4 were inseminated with extended semen in ratio 1: 1, 1:2 and 1: 3 (semen: extender), respectively and were all intramuscularly induced using $0.8 \mu \mathrm{g}$ of buserelin after insemination. Results showed that some of the does induced with buserelin acetate intramuscularly (treatments 2, 3 and 4) were pregnant, while none of the control rabbits was pregnant. The ratio 1: 1 extended semen (treatment 2) recorded the highest percentage conception (85.71\%) followed by treatment 3 $(71.43 \%)$ and treatment $4(57.14 \%)$. There was significant $(P<0.05)$ difference in gestation length (32.50, 31.00 and 32.75), litter size (4.83, 8.60 and 3.25), live kits at birth (3.50, 6.60 and 1.75) for treatments 2, 3 and 4 respectively and the average litter weight was not significantly different among the treatments. This study suggests that diluting semen in ratio 1: 1 produced highest conception rate with intramuscular administration of $0.8 \mu \mathrm{g}$ buserelin acetate than extending semen in ratios 1: 2 and 1: 3 .

\section{Keywords: Rabbit does, ovulation induction, buserelin acetate, semen extender, artificial insemination. \\ Introduction \\ The productivity of rabbit farms has increased and become more homogeneous through the use of Artificial Insemination (AI), cycled production and very prolific genetic strains (Castellini, 2007). Ovulation of rabbit does is induced through a neurohormonal reflex initiated during mating (Julie and Michael, 2000). Hence, in the absence of a male, ovulation has to be induced by artificial methods (Ewuola et al., \\ 2015). The ovulation inducing method most frequently used is an intramuscular injection of gonadotropin-releasing hormone $(\mathrm{GnRH})$ or its synthetic analogues (Battaglini et al., 1982). Intramuscular injection of GnRH synthetic analogues at the time of AI was used in the ovulation induction of rabbit does more than 20 years ago (Rodriguez and Ubilla, 1988). In addition, it was found that GnRH and its analogues can be used repeatedly without}


interfering the immune response of hosts (Adams, 1981; Kalaba and Abdel-Khalek., 2011). However, extenders play a key role in long - term storage of rabbit semen, because they provide the nutrients needed for the metabolic maintenance of sperm cells, control the $\mathrm{pH}$ and the osmotic pressure of the medium (Castellini, 1996, Roca et al., 2000, Carluccio et al., 2004, ElKelawy et al., 2012). Rabbit semen extender had enhanced sperm characteristics and improved fertility and prolificacy (El-Speiy et al., 2014).

The aim of this study were therefore: (a) to determine the fertility rate of rabbit does induced with buserelin acetate inseminated with extended semen and(b) to determine the best dilution ratio of semen and extender with intramuscular administration of micro dose of buserelin for ovulation induction.

\section{Materials and methods Experimental Site}

The study was carried out at the rabbitry unit of Teaching and Research Farm,
University of Ibadan, Ibadan, Oyo State Nigeria.

\section{Experimental animals and Management}

Twenty eight multiparous rabbit does was used for this experiment and the rabbit does were housed individually in a single cell compartment of wooden cage, in open sided pen with good cross ventilation. The rabbit does were fed concentrate diet during the experimental period. Feed and cool clean water were provided ad libitum.

Semen collection, evaluation and extension

Semen was collected from selected active bucks using an artificial vagina (AV) and semen from each buck was pooled into a well labelled eppendorff tube; semen evaluation was carried out to determine the semen quality parameters. After semen evaluation, ejaculates from ten rabbit bucks with more than $60 \%$ motility and less than $10 \%$ abnormal sperm cells were pooled and extended at varying dilution ratio. The semen was diluted at room temperature $\left(27^{\circ}-29^{\circ} \mathrm{C}\right)$. See Table 1 below for composition of conventional extender.

Table 1: Composition of Extender

$\begin{array}{ll}\text { Ingredients } & \text { Composition } \\ \text { Glucose } & 58 \mathrm{mg} \\ \text { Sodium citrate } & 5 \mathrm{~g} \\ \text { Egg yolk } & 20 \mathrm{mls} \\ \text { Penicillin G } & 1 \mathrm{mg} / 1000 \mathrm{mls} \\ \text { Streptomycin } & 1 \mathrm{mg} / \mathrm{ml}\end{array}$

\section{All dissolve in $100 \mathrm{mls}$ distilled water}

\section{Experimental layout}

The twenty eight multiparous rabbit does were randomly allotted into four (4) treatments of seven does each. All the does were hormonally synchronized intramuscularly for oestrus. The hormonal treatment consists of 20IU of PMSG per doe, injected intramuscularly 48 hours before AI. Treatment 1 serves as control (no induction but intramuscularly injected with normal saline), does on treatments 2, 3 and 4 were induced using $0.8 \mu \mathrm{g}$ of buserelin (i.m) at $0.1 \mathrm{~mL} /$ doe immediately after insemination.

Treatment 1:Unextended semen + no induction (Control)

Treatment 2: Extended semen (1:1) + Intramuscular induction

Treatment 3: Extended semen (1:2) + Intramuscular induction 


\section{Ewuola, Omotosho and Adeyemi}

Treatment 4: Extended semen (1:3) + Intramuscular induction

Note: The ratio was semen: extender

\section{Statistical analysis}

Data were subjected to descriptive statistics and analysis of variance using the general linear model of SAS (2003) at $\alpha_{0.05}$ and treatment means were compared using Duncan's Multiple Range Test of the same software.

\section{Results}

The conception rate of rabbit does administered micro dose $(0.8 \mu \mathrm{g})$ of buserelin acetate intramuscularly and inseminated with extended semen are presented in Figure 1. Some of the does induced with buserelin acetate intramuscularly (treatments 2, 3 and 4) were pregnant, while no conception was recorded in does that were control (treatment 1). The ratio 1: 1 extended semen (treatment 2) recorded the highest percentage conception (85.71\%) followed by treatment $3(71.43 \%)$ and treatment $4(57.14 \%)$. Table 2 shows the mean values of gestation length, litter size, live kit at birth, average litter weight per doe and productivity index, obtained in the rabbit does that were induced intramuscularly. All the parameters were significantly $(\mathrm{P}<0.05)$ different except in average litter weight among the treatments. The highest litter size of $8.60 \pm 1.33$ was recorded in does on treatment 3 while the lowest litter size of $3.2 \pm 1.03$ was recorded in does on treatment 4 . The does inseminated with 1:2 extended semen (treatment 3) had higher number of live kits at birth $(6.60 \pm 1.57)$ and productivity index

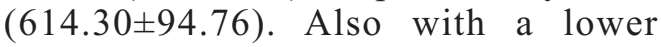
gestation length $(31.00 \pm 0.44)$ and average litter weight $(32.61 \pm 3.36)$ than that of rabbit does inseminated with extended semen 1:1 (treatment 2) and 1:3 (treatment 4). There was no significant difference in the average litter weight across the treatments but rabbit does on treatment 2 (38.89 \pm 5.66$)$ had higher litter weight than that of rabbit does on treatments 3 (32.61 \pm 3.36$)$ and $4(36.17 \pm 2.90)$.

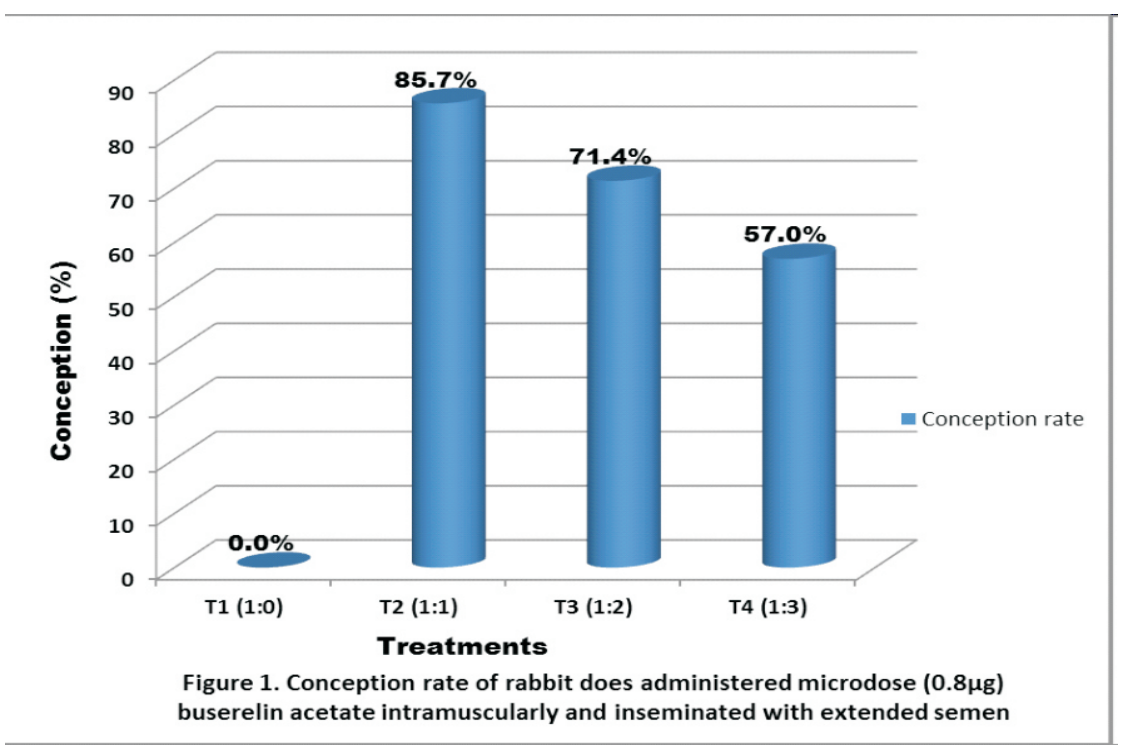

T1 = Unextended Semen, T2 - T4 = (Semen: Extender v/v $)$ and induced intramuscularly 
Effects of Buserelin acetate and semen extension on fertility in rabbit does under artificial insemination

Table 2: Fertility rate of rabbit does administered $0.8 \mu \mathrm{g}$ buserelin acetate intramuscularly and inseminated with extended semen

\begin{tabular}{lccc}
\hline \multirow{2}{*}{ Parameters } & \multicolumn{3}{c}{ Treatments (Different dilution ratio) } \\
& T2 (1:1) & T3 (1:2) & T4 (1:3) \\
\hline Litter size & $4.83 \pm 1.30^{\mathrm{a}}$ & $8.60 \pm 1.33^{\mathrm{ab}}$ & $3.25 \pm 1.03^{\mathrm{b}}$ \\
Gestation length (days) & $32.50 \pm 0.34^{\mathrm{a}}$ & $31.00 \pm 0.44^{\mathrm{b}}$ & $32.75 \pm 0.48^{\mathrm{a}}$ \\
Average litter weight $(\mathrm{g})$ & $38.89 \pm 5.66$ & $32.61 \pm 3.36$ & $36.17 \pm 2.90$ \\
Live kits at birth & $3.50 \pm 1.18^{\mathrm{ab}}$ & $6.60 \pm 1.57^{\mathrm{a}}$ & $1.75 \pm 1.44^{\mathrm{b}}$ \\
Productivity index & $414.30 \pm 111.57^{\mathrm{ab}}$ & $614.30 \pm 94.76^{\mathrm{a}}$ & $185.70 \pm 58.89^{\mathrm{b}}$ \\
\hline
\end{tabular}

ab: Means with different superscripts in the same row are significantly $(\mathrm{P}<0.05)$ different

\section{Discussion}

The use of gonadotropin releasing hormone $(\mathrm{GnRH})$ analogue (Buserelin acetate) have been adjudged to be potent in inducing ovulation thereby increasing fertility rate in animal breeding programme (Quintela et al., 2004).

It was observed that the intramuscular (i.m) administration of $0.8 \boldsymbol{\mu} \mathrm{g}$ of buserelin acetate resulted in the conception rate of $85.71 \%$, $71.43 \%$ and $57.14 \%$ which decreased as the ratio of semen to extender increased. This implied that rabbit semen can be extended up to ratio $1: 2$ to get conception rate above $70 \%$ in rabbit does. However, low conception rate in does inseminated with semen extended four times it original volume could be attributed to reduction in the number of motile sperm cells in the extended semen dose, since uniform volume of the extended semen were inseminated irrespective of the dilution ratio. This result agreed with the finding of El-Kelawy et al. (2012) who studied the viability and fertilizing ability of extended rabbit semen. The authors compared glucose-yolk citrate extender with saline solution and fructose-yolk tris extender at the dilution rate of 1 (semen) : 5 (extender) $\mathrm{v} / \mathrm{v}$, and concluded that the glucose-yolk citrate significantly depressed fertility at the dilution rate of $1: 5$ and increased the gestation length without affecting growth or pre-weaning viability. El-Speiy et al. (2014) have also reported that the use of extender as in this study usually enhanced semen quality and fertility in animal reproduction. It was also evidence in this study that none of the does that were not treated with buserelin (Treatment 1) was pregnant despite the fact that they were inseminated with unextended semen which was expected to have highest sperm concentration. This ascertained that ovulation induction is a requisite to conception in rabbit does under artificial insemination as also reported by Rodriguez and Ubilla (1988) and Ewuola et al. (2015). The gestation lengths in does on treatment 4 (32.75 \pm 0.48$)$ were significantly higher than that on treatment $2(32.50 \pm 0.34)$ and 3 $(31.00 \pm 0.44)$. Finding from this work collaborates the report of El-Kelawy et al. (2012) who reported that extending semen in ratio of 1 (semen) : 5 (extender) v/v increased the gestation length in rabbit does.

\section{Conclusion}

This research work has demonstrated the possibility of ovulation to enhance conception rate and increase productivity in rabbits using artificial insemination technique. From this study, intramuscular administration of buserelin acetate initiates conception at $0.8 \mu \mathrm{g}$. Also the dilution ratio of 1: 1 (semen: extender) produced optimal conception when ovulation is induce with 
the intramuscular administration of buserelin.

\section{References}

Adams, C. E. 1981. Artificial insemination in the rabbit: The technique and application to practice. Journal of Applied Rabbit Research 4: 10-13.

Battaglini, M., Constantini, F., Baldissera, C. N. and Castrovilli, C. F. 1982. Induction of ovulation and artificial insemination in the rabbit. Conigli-coltura 1982, 19:45-54.

Carluccio, A., Robbe, D., De Amicis, I., Contri, A., Russo, F. and Paoletti, M. 2004. Arti?cial insemination in rabbits: laboratory and ? eld trial with three different semen extenders. World Rabbit Sci. 12:65-79.

Castellini, C. 1996. Recent advances in rabbit artificial insemination. In Proceedings of the 6th World Rabbit Congress, Toulouse, France, 2: 13-26.

Castellini, C. 2007. Reproductive activity and welfare of rabbit does. Ital. $J$. Anim. Sci. 6, 743-747.

El-Kelawy, H. M., Tawfeek, M. I., ElGaafary, M. N. and Ibrahim, H. 2012. Viability And Fertilizing Ability of Extended Rabbit Semen Stored At $5^{\circ} \mathrm{C}$. Proceedings 10 th World Rabbit Congress - September 3 - 6, 2012Sharm El-Sheikh-Egypt, 285 - 289.

El-Speiy, M. E., Elkomy Alaa, E. and Kamel, K. I. 2014. Effect of Adding Protein High Viscosity (Gelatin) in Tris Extender on Semen Conservation Status, Fertility Rates, Antioxidant Status and Sex Ratio of Rabbits. Global Veterinaria 12 (6): 840-849.

Ewuola, E. O, Ojeniyi, O. O, Adeyemi, A. A, Lawanson, A. A and Oni, A. A (2015). Effect of Buserelin Acetate on the Fertility Rate of Synchronised Rabbit Does Artificially Inseminated.
Nigerian Journal of Animal Science, Volume $17(1,2) 2015$

Julie, B. and Michael J. B, 2000. Neuroendocrine Regulation of GnRH Release in Induced Ovulators. Frontiers in Neuroendocrinology, 21, 220-262.

Kalaba, Z. M. and Abdel-Khalek, A. E. 2011. Effect of repeated GnRH injection and intra-vaginal mechanical stimulation on reproductive performance of doe rabbits. Asian Journal of Animal and Veterinary Advances, 6, 1010-1018.

Quintela, L. A., Pena, A. I., Vega, M. D., Gullon, J., Prieto, M. C., Barrio, M., Becerra, J. J., Maseda, F. and Herradon, P. G. 2004. Ovulation induction in rabbit does submitted to artificial insemination by adding buserelin to the seminal dose. Reprod. Nutr. Dev., 44, 79-88.

Roca, J., Martínez, S., Vázquez, J. M., Lucas, X., Parrilla, I. and Martínez, E. A. 2000. Viability and fertility of rabbit spermatozoa diluted in Trisbuffer extenders and stored at $15^{\circ} \mathrm{C}$. Animal Reproduction Science. 64: (12), pp. 103-112.

Rodriguez, J. M. and Ubilla, E. 1988. Effects of sexual receptivity on ovulation response in rabbits does induced with GnRH. Proc. $4^{\text {th }}$ World Rabbit Congr., Budapest, 504-509.

SAS. 2003. Statistical Analysis System . SAS stat. Version 9. SAS Institute Inc. Gary NC U.S.A.

Viudes de Castro, M. P., Lavara, R., Marco-Jimènez, F., Cortell, C. and Vicente J. S. 2007. Ovulation induced by mucosa vaginal absorption of buserelin and triptorelin in rabbit. Theriogenology 68, 1031-1036. 
Effects of Buserelin acetate and semen extension on fertility in rabbit does under artificial insemination

Zapletal, D. and Pavlik, A. 2008. The effect of lecirelin $(\mathrm{GnRH})$ dosage on the reproductive performance of nulliparous and lactating rabbit does. Animal Reproduction Science, 104: 306-315.

Received: $28^{\text {th }}$ November, 2016

Accepted: $12^{\text {th }}$ February, 2017 